\title{
Hubungan Pemberian Asi dan Mpasi dengan Tingkat Kecukupan Gizi Baduta pada Keluarga Nelayan
}

\author{
Novi Kardyanti ${ }^{1 *}$, Suyatno ${ }^{2}$, Martha Irene Kartasurya ${ }^{2}$ \\ 1 Peminatan Gizi Kesehatan Masyarakat, Fakultas Kesehatan Masyarakat Universitas Diponegoro \\ 2 Bagian Gizi Kesehatan Masyarakat, Fakultas Kesehatan Masyarakat Universitas Diponegoro \\ ${ }^{*}$ Corresponding author : kardyantinovi@gmail.com
}

\begin{abstract}
ABSTRAK
Praktik pemberian ASI dan MPASI perlu memperhatikan kualitas dan kuantitas yang sesuai agar asupan zat gizi baduta terpenuhi secara maksimal. Tujuan penelitian untuk menganalisis hubungan pemberian ASI dan MPASI dengan tingkat kecukupan energi (TKE) dan protein (TKP) baduta usia 624 bulan di desa nelayan Kabupaten Demak. Jenis penelitian explanatory research ini menggunakan desain cross sectional. Subjek penelitian (61 orang) dipilih secara purposive, menggunakan kriteria inklusi: masih diberi ASI, memiliki ayah nelayan serta tidak cacat fisik dan mental. Pengumpulan data dengan wawancara menggunakan kuesioner terstruktur. Analisis dilakukan dengan uji korelasi Rank spearman, dan Chi Square. Hasil penelitian menunjukkan rerata frekuensi pemberian ASI usia 6-12 bulan 9,1 kali/hari dan 12-24 bulan 6,9 kali/hari. Rerata durasi pemberian ASI 122,5 menit/hari. Baduta dengan pemberian MPASI lokal 65,6\%, tekstur MPASI yang kurang sesuai $37,7 \%$, rerata TKE 82,7\%, kontribusi energi ASI 47,4\%, kontribusi energi MPASI 40,5\%, TKP 115,3\%, kontribusi protein ASI $46,8 \%$, kontribusi protein MPASI 84,5\%. Ada hubungan antara frekuensi $(p=0,008, r=0,336)$ dan durasi $(p=0,001, r=0,412)$ pemberian ASI dengan TKE Baduta, tetapi tidak berhubungan dengan TKP baduta. Ada hubungan frekuensi pemberian MPASI $(p=0,006, r=0,351)$ dan jenis MPASI $(p=0,043)$ terhadap TKP Baduta. Hasil penelitian menunjukkan bahwa semakin bertambah usia baduta semakin sedikit kandungan zat gizi yang di peroleh dari ASI, sehingga pemberian MPASI perlu diperhatikan baik dari frekuensi dan jenis MPASI yang diberikan.
\end{abstract}

Kata Kunci : ASI, MPASI, TKE, TKP

\section{PENDAHULUAN}

Pemenuhan kebutuhan makanan atau asupan gizi pada baduta $6-24$ bulan meliputi frekuensi dan durasi pemberian ASI serta pemberian MPASI yang meliputi ketepatan waktu, kesesuaian tekstur, serta jenis MPASI yang diberikan. ${ }^{1}$ Rekomendasi yang diberikan oleh WHO dan Unicef ada empat hal yang perlu diperhatikan dalam mencapai pertumbuhan optimal, diantaranya pemberian ASI pasca 30 menit dilahirkan, ASI ekslusif, pemberian ASI sampai 2 tahun serta pemberian makanan pendamping pada usia $6-24$ bulan. $^{2}$

Presentase pemberian ASI ekslusif di Indonesia sebesar $46,74 \%$, di Jawa Tengah $65,57 \%$ pada tahun 2018 dan di Kabupaten Demak $65,87 \%{ }^{3}$ Cakupan pemberian ASI eksklusif Puskesmas Bonang II pada tahun 2018 sebesar 36,34\%. Rendahnya angka pemberian ASI ekslusif tersebut menunjukkan masih banyak praktik pemberian MPASI dini yang dilakukan.

Praktek pemberian MPASI perlu memperhatikan ketepatan usia agar tidak terjadi keterlambatan pertumbuhan serta adanya gangguan pencernaan. Tekstur MPASI diberikan secara bertahap dari mulai makanan cair dan lunak. Selain tekstur, variasi makanan yang diberikan kepada baduta $6-24$ bulan juga harus terus ditingkatkan. Pemberian MPASI dapat berupa makanan lokal atau instan (pabrik). ${ }^{4}$

Praktik pemberian ASI dan MPASI pada baduta yang salah dapat berpengaruh terhadap jumlah asupan gizi yang diterima baduta. Asupan gizi yang tidak kuat dapat berpengaruh terhadap kejadian gagal tumbuh anak. Faktor yang mempengaruhi masih banyaknya pemberian ASI dan MPASI yang kurang tepat diantaranya faktor biologi yaitu, faktor ibu paritas, pemakaian kontrasepsi, serta kesehatan ibu dan bayi. Faktor sosial budaya diantaranya terkait nilai yang dipercaya, pengaruh iklan, pengaruh petugas kesehatan, tingkat pendidikan orang ibu, pekerjaan ibu serta pengetahuan ibu. Faktor ekonomi yaitu terkait pendapatan keluarga. ${ }^{5}$

Desa Betahwalang merupakan desa yang berada di wilayah pesisir Demak dengan sebagian besar profesi masyarakatnya nelayan tradisional. Nelayan tradisional cenderung memperoleh hasil tangkapan sedikit, sehingga berpengaruh terhadap masalah ekonomi yang berdampak terhadap pemenuhan kebutuhan 


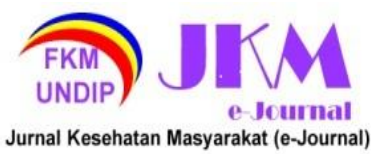

mereka, terutama kebutuhan gizi. Berdasarkan latar belakang tersebut maka dilakukan penelitian terkait hubungan pemberian ASI dan MPASI dengan tingkat kecukupan energi dan protein baduta pada keluarga nelayan desa Betahwalang.

\section{METODE PENELITIAN}

Penelitian ini merupakan suatu penelitian penjelasan yang dilakukan dengan disain cross sectional. Populasi penelitian yaitu baduta yang terdaftar pada 4 posyandu desa Betahwalang, berusia 6 sampai 24 bulan yang berjumlah 128 baduta, Berdasar perhitungan sampel, besar sampel minimal adalah 61 baduta. Badita kemudian dipilih secara purposive sampling. Kriteria inklusi subjek dalam penelitian ini adalah berusia 6 sampai 24 bulan, memiliki ayah seorang nelayan, masih diberi ASI dan ibu bersedia menjadi responden penelitian. Baduta dengan riwayat penyakit kronis dan cacat fisik maupun mental tidak diikutsertakan. Data primer didapatkan melalui observasi secara langsung dan wawancara kepada responden (ibu baduta) menggunakan kuesioner terstruktur

Hasil uji normalitas data dengan menggunakan uji Kolmogorov Smirnov menunjukkan frekuensi pemberian ASI, durasi pemberian ASI, frekuensi pemberian MPASI dan tingkat kecukupan energi baduta berdistribusi tidak normal, sedangkan tingkat kecukupan protein berdistribusi normal. Hubungan antara frekuensi dan durasi pemberian ASI dengan tingkat kecukupan energi dan protein, frekuensi pemberian MPASI dengan tingkat kecukupan energi protein baduta diuji dengan korelasi Rank Spearman.Hubungan tekstur MPASI dan jenis MPASI dengan tingkat kecukupan energi protein dan status amtropometri baduta diuji menggunakan Chi Square

Tabel 1. Tabel Karakteristik Variabel Penelitian

\section{HASIL}

Karakteristik subjek dan status antropometri baduta disajikan pada Tabel 1 . Rerata lama pendidikan ibu 9,5 tahun, yang berarti telah menyelesaikan pendidikan dasar. Rerata usia ibu baduta adalah 28 tahun, dan sebagian besar ibu baduta tidak bekerja $(88,5 \%)$. Perbandingan jenis kelamin baduta yang menjadi subjek penelitian antara laki-laki dan perempuan hampir sama. Rerata usia baduta adalah 13,5 bulan.

Rerata frekuensi pemberian ASI pada baduta usia 6 - 12 bulan sebanyak 9,1 kali/hari dengan frekuensi paling sedikit $6 \mathrm{kali} / \mathrm{hari}$ dan paling banyak 15 kali/hari. Frekuensi pemberian ASI pada baduta usia 12-24 bulan memliki rerata $6,9 \mathrm{kali} / \mathrm{hari}$ dengan pemberian minimum 3 kali/hari dan maksimum 10 kali/hari. Rerata durasi pemberian ASI harian baduta adalah 122,5 menit. Rerata frekuensi pemberian MPASI pada baduta 2 kali/hari, sebagian besar baduta memperoleh jenis MPASI lokal $(65,6 \%)$, dan pemberian tekstur MPASI yang sudah sesuai sebesar $(62,3 \%)$. Rerata tingkat kecukupan energi total yang diperoleh baduta sebesar $90,4 \%$ dan tingkat kecukupan proteion total $106,8 \%$.

Hasil analisis bivariat pada Tabel 2 menunjukkan frekuensi dan durasi pemberian ASI baduta berhubungan dengan tingkat kecukupan energi total baduta tetapi tidak berhubungan dengan tingkat kecukupan protein total baduta. Frekuensi pemberian MPASI dan jenis MPASI berhubungan dengan tingkat kecukupan protein total baduta tetapi tidak berhubungan dengan tingkat kecukupan protein total baduta. Kesesuaian tekstur MPASI tidak berhubungan tingkat kecukupan energi dan protein total baduta.

\begin{tabular}{|c|c|c|c|c|c|c|c|}
\hline \multicolumn{2}{|c|}{ Variabel } & $\mathbf{N}$ & $\%$ & Rerata & $\begin{array}{l}\text { Standar } \\
\text { Deviasi }\end{array}$ & $\begin{array}{l}\text { Nilai } \\
\text { Min }\end{array}$ & $\begin{array}{l}\text { Nilai } \\
\text { Maks }\end{array}$ \\
\hline \multicolumn{2}{|c|}{ Lama Pendidikan Ibu dalam Tahun } & $\pi$ & & 9,48 & 2,27 & 6 & 16 \\
\hline Status Pekerjaan Ibu & $\begin{array}{l}\text { Tidak Bekerja } \\
\text { Bekerja }\end{array}$ & $\begin{array}{r}54 \\
7\end{array}$ & $\begin{array}{l}88,5 \\
11,5\end{array}$ & & & & \\
\hline \multirow{2}{*}{\multicolumn{2}{|c|}{$\begin{array}{l}\text { Usia Ibu Baduta (tahun) } \\
\text { Usia Baduta (bulan) }\end{array}$}} & & & 28 & 6,23 & 20 & 45 \\
\hline & & & & 13,5 & 6,01 & 56 & 24 \\
\hline Jenis Kelamin Baduta & $\begin{array}{l}\text { Laki-laki } \\
\text { Perempuan }\end{array}$ & $\begin{array}{l}31 \\
30\end{array}$ & $\begin{array}{l}50,8 \\
49,2\end{array}$ & & & & \\
\hline \multicolumn{2}{|c|}{ Frekuensi Pemberian ASI } & & & 8,5 & 2,71 & 3 & 15 \\
\hline & 6-12 bulan & & & 9,1 & 2,00 & 6 & 15 \\
\hline & 12-24 bulan & & & 6,9 & 1,87 & 3 & 10 \\
\hline Durasi Pemberian ASI (m & lenit/Hari) & & & 122,5 & 53,62 & 40 & 540 \\
\hline Frekuensi Pemberian MF & ASI (kali/hari) & & & 2,23 & 0,53 & 1 & 3 \\
\hline
\end{tabular}




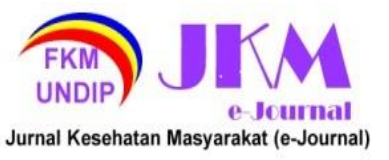

JURNAL KESEHATAN MASYARAKAT (e-Journal)

Volume 9, Nomor 5, September 2021

ISSN: 2715-5617 / e-ISSN: 2356-3346

http://ejournal3.undip.ac.id/index.php/jkm

\begin{tabular}{|c|c|c|c|c|c|c|c|}
\hline \multicolumn{2}{|c|}{ Variabel } & $\mathbf{N}$ & $\%$ & Rerata & $\begin{array}{l}\text { Standar } \\
\text { Deviasi }\end{array}$ & $\begin{array}{l}\text { Nilai } \\
\text { Min }\end{array}$ & $\begin{array}{l}\text { Nilai } \\
\text { Maks }\end{array}$ \\
\hline Jenis MPASI & $\begin{array}{l}\text { Lokal } \\
\text { Instan } \\
\text { lokal dan Instan }\end{array}$ & $\begin{array}{r}40 \\
9 \\
12\end{array}$ & $\begin{array}{l}65,6 \\
14,8 \\
19,7\end{array}$ & & & & \\
\hline $\begin{array}{ll}\text { Kesesuaian } & \text { Tekstur } \\
\text { MPASI } & \end{array}$ & $\begin{array}{l}\text { Kurang Sesuai } \\
\text { Sesuai }\end{array}$ & $\begin{array}{l}23 \\
38\end{array}$ & $\begin{array}{l}37,7 \\
62,3\end{array}$ & & & & \\
\hline $\begin{array}{l}\text { TKE (\%) } \\
\text { Kontribusi ASI (\%) } \\
\text { Kontribusi MPASI (\%) } \\
\text { TKP (\%) } \\
\text { Kontribusi ASI (\%) } \\
\text { Kontribusi MPASI (\%) }\end{array}$ & & & & $\begin{array}{r}90,4 \\
56,3 \\
34,1 \\
106,8 \\
54,1 \\
52,8 \\
\end{array}$ & $\begin{array}{r}10,2 \\
15,56 \\
11,93 \\
23,03 \\
10,37 \\
32,92 \\
\end{array}$ & $\begin{array}{r}58,32 \\
24,3 \\
19,9 \\
70,1 \\
32,5 \\
25,7 \\
\end{array}$ & $\begin{array}{r}99,63 \\
80,0 \\
76,7 \\
166,3 \\
70,5 \\
149,8 \\
\end{array}$ \\
\hline
\end{tabular}

Tabel 2. Hasil Uji Hubungan

\begin{tabular}{lccc}
\multicolumn{1}{c}{ Variabel bebas } & $\begin{array}{c}\text { Variabel } \\
\text { Terikat }\end{array}$ & $\boldsymbol{R}$ (Korelasi) & $\boldsymbol{p}$-value \\
\hline Frekuensi Pemberian ASI & TKE Total & 0,336 & $\mathbf{0 , 0 0 8 ^ { \mathbf { a } }}$ \\
& TKP Total & 0,024 & $0,824^{\mathrm{a}}$ \\
Durasi Pemberian & TKE Total & 0,412 & $\mathbf{0 , 0 0 1 ^ { \mathbf { a } }}$ \\
& TKP Total & 0,104 & $0,424^{\mathrm{a}}$ \\
Frekuensi Pemberian MPASI & TKE Total & 0,080 & $0,541^{\mathrm{a}}$ \\
& TKP Total & 0,351 & $\mathbf{0 , 0 0 6 ^ { \mathbf { a } }}$ \\
Kesesuaian Tekstur MPASI & TKE Total & - & $0,019^{\mathrm{b}}$ \\
Jenis MPASI & TKP Total & - & $0,462^{\mathrm{b}}$ \\
& TKE Total & - & $\mathbf{0 , 0 6 7 7 ^ { \mathrm { b } }}$ \\
\hline
\end{tabular}

a* Uji Korelasi Rank Spearman

$\mathrm{b}^{*}$ Uji Chi Square

\section{PEMBAHASAN}

Hubungan Pemberian ASI (Frekuensi

Pemberian dan Durasi Pemberian ASI) dengan TKE Baduta (Usia 6-24 bulan)

Frekuensi pemberian ASI berhuungan dengan TKE baduta $(p=0,008, \quad r=0,336)$. Koefisien korelasi menunjukkan arah hubungan yang positif, sehingga semakin banyak pemberian ASI yang dilakukan semakin besar TKE baduta yang didapat.

Penelitian menunjukkan rerata TKE seluruh baduta sebesar $34,0 \%$, sedangkan rerata kontribusi ASI terhadap TKE sebesar $56,3 \%$. Rerata kontribusi ASI pada baduta dibawah satu tahun dengan pemberian ASI kurang dari 8 kali terhadap TKE sebesar $57,6 \%$, sedangkan baduta dengan pemberian lebih dari 8 kali memiliki kontribusi terhadap TKE sebesar $63,56 \%$. Baduta diatas satu tahun dengan pemberian kurang dari rerata dalam sehari mendapatkan rerata kontribusi ASI terhadap TKE sebesar 30,9\%, sedangkan dengan pemberian lebih dari rerata mendapatkan kontribusi sebsar $35,1 \%$.

Hasil tersebut menunjukkan bahwa semakin banyak pemberian ASI yang dilakukan semakin besar tingkat kecukupan energi yang diperoleh baduta, tetapi semakin bertambah usia baduta semakin sedikit kandungan energi pada ASI.

Sejalan dengan penelitian sebelumnya yang dilaksanakan di Kelurahan Pannampu Makassar terhadap baduta dengan usia 6-24 bulan sebanyak 60 baduta. Hasil yang menunjukan baduta dengan frekuensi pemberian ASI yang kurang berisiko 3,75 kali kekurangan zat gizi. ${ }^{6}$ Bayi yang mendapatkan ASI dengan frekuensi yang tepat akan memperoleh semua kelebihan ASI serta kebutuhan gizinya akan terpenuhi secara maksimal dan membuat bayi lebih sehat, tidak mudah terinfeksi dan tidak mudah sakit, yang dapat memudahkan pertumbuhan dan perkembangannya. ${ }^{7}$

Durasi pemberian dengan tingkat kecukupan energi baduta memiliki hubungan yang signifikan $(p=0,001, r=0,412)$. Hasil crosstab menunjukkan sebagian besar baduta dengan durasi pemberian ASI yang kurang memiliki TKE yang kurang yaitu sebesar $54,3 \%$, sedangkan baduta dengan durasi pemberian ASI yang cukup sebagian besar memiliki TKE yang cukup pula sebesar $65,4 \%$. 


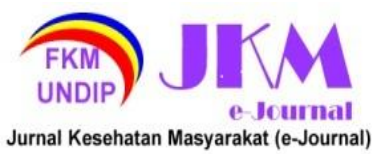

Hasil penelitian menunjukkan baduta usia $6-8$ bulan yang mendapatkan pemberian ASI kurang dari 120 menit dalam sehari mendapatkan kontribusi terhadap TKE sebesar $69,1 \%$ dan yang lebih dari rerata (120 menit) sebesar $72,9 \%$. Baduta usia 9 - 11 bulan dengan pemberian ASI kurang dari rerata (100 menit) mendapatkan kontribusi terhadap TKE sebesar 56,9\% dan yang lebih dari 100 menit sebesar $58,3 \%$.. Baduta usia lebih dari satu tahun dengan pemberian ASI kurang dari rerata (80 menit) mendapatkan kontribusi terhadap TKE sebesar $35,6 \%$ dan yang mendapat pemberian kurang sebesar $37,6 \%$. Hasil tersebut menunjukkan bahwa baduta dengan durasi pemberian ASI yang lama mendapatkan kontribusi terhaadap TKE yang besar pula, tetapi semakin bertambah usia baduta semakin sedikit kontribusi energi yang diperoleh dari ASI.

Baduta dengan pemberian ASI yang lama akan memperoleh kandungan gizi yang cukup dari ASI. Penelitian sebelumnya yang dilaksanakan di kelurahan Pannampu kota Makasar menunjukkan baduta dengan durasi atau lama pemberian ASI yang kurang memeliki risisko kekurangan zat gizi sebesar 3,75 kali dibandingkan dengan baduta yang mendapatkan lama pemberian ASI yang cukup. ${ }^{6}$ $\begin{array}{llr}\text { Hubungan Pemberian ASI (Frekuensi } & \text { A } \\ \text { Pemberian dan Durasi } & \text { Pemberian ASI) } \\ \text { dengan TKP Baduta (Usia } & 6-24 \text { bulan) }\end{array}$

Frekuensi pemberian ASI dengan tingkat kecukupan protein baduta menunjukkan tidak adanya hubungan $(p=0,824, r=0,024)$. Hasil penelitian menunjukkan rerata kontribusi ASI terhadap TKP baduta usia $6-8$ bulan dengan frekuensi pemberian ASI kurang sebesar $52,7 \%$ dan yang cukup sebesar 61,9\%. Rerata kontribusi ASI terhadap TKP baduta usia 9 - 11 bulan dengan frekuensi pemberian ASI kurang sebesar $48,5 \%$ dan yang lebih sebesar $49,8 \%$. Baduta usia $12-24$ bulan mendapatkan kontribusi ASI terhadap TKP dengan frekuensi pemberian ASI yang kurang sebesar $30,9 \%$ dan dengan frekuensi pemberian ASI yang cukup sebesar $35,1 \%$.

Tidak ada hubungan antara durasi pemberian ASI dengan tingkat kecukupan protein baduta $(p=0,424, r=0,104)$. Hasil penelitian menunjukkan rerata kontribusi protein yang didapat baduta dari ASI sebesar $54,4 \%$. Baduta $6-8$ bulan dengan rata-rata durasi pemberian yang kurang mendapatkan kontribusi portein dari ASI sebesar 3,7\%\% lebih rendah dibandingkan baduta dengan durasi pemberian ASI yang cukup. Baduta usia 9 bulan ke atas dengan durasi pemberian ASI yang kurang mendapatkan kontribusi protein $1,2 \%$ lebih rendah dibandingkan baduta dengan durasi pemberian ASI yang cukup.

Semakin bertambah usia baduta semakin sedikit kontribusi zat gizi yang diperoleh dari ASI. $^{14}$ Asupan protein yang diterima oleh baduta Betahwalang sebagian besar diperoleh dari MPASI, sehingga kontribusi MPASI terhadap protein lebih besar dibandingkan dengan ASI. Hal tersebut berkaitan dengan letak desa Betahwalang yang berada di wilayah pesisir Kabupaten Demak sehingga sebagian besar masyarakatnya memanfaatkan hasil laut untuk dijadikan makanan sehari-hari, begitu pula dengan makanan yang diberikan kepada baduta. Sebagian besar asupan protein yang dikonsumsi baduta berasal dari MPASI.

Hubungan Pemberian MPASI (Frekuensi Pemberian, Kesesuaian Tekstur dan Jenis MPASI) dengan TKE dan TKP Baduta (Usia 6-24 bulan)

Frekuensi pemberian MPASI tidak berhubungan dengan tingkat kecukupan energi baduta $(p=0,541)$ tetapi berhubungan dengan tingkat kecukupan protein baduta $(p=0,006)$. Hasil penelitian menunjukkan rerata TKE dari MPASI $(34,1 \%)$ lebih rendah dibanding TKE dari ASI $(56,3 \%)$. Hasil penelitian menunjukkan baduta usia $6-8$ bulan dengan frekuensi pemberian MPASI $1 \mathrm{kali} /$ hari mendapatkan kontribusi terhadap TKE sebesar 17,2\% dan dengan pemberian 2 kali/hari mendaptkan kontribusi sebsar $32,9 \%$. Baduta usia $9-11$ bulan dengan frekuensi pemberian MPASI 2 kali/hari memperoleh kontribusi terhadap TKE sebesar $26,4 \%$ dan $37,8 \%$ pada frekuensi 3 kali/hari, sedangkan baduta usia diatas satu tahun dengan frekuensi pemberian 2 kali /hari mendapatkan kontribusi terhadap TKE sebesar $43,6 \%$ dan dengan pemberian $3 \mathrm{kali} / \mathrm{hari}$ mendapatkan kontribusi sebesar $46,2 \%$. Hasil tersebut menunjukkan bahwa semakin bertambah usia baduta semakin banyak frekuensi pemberian yang harus dilakukan ibu baduta agar TKE dapat terpenuhi.

Frekuemsi pemberian MPASI yang dilakukan sebagian besar kurang sesuai dengan prinsip MPASI. Kebutuhan energi baduta sebagian besar diperoleh dari makanan pokok yaitu nasi. Nasi yang diberikan kepada baduta rata-rata hanya 2 - 3 sendok makan dalam sekali pemberian.

Hasil penelitian ini sejalan dengan penelitian sebelumnya yang menyatakan bahwa kurangnya tingkat kecukupan energi bukan hanya disebabkan dari frekuensi 


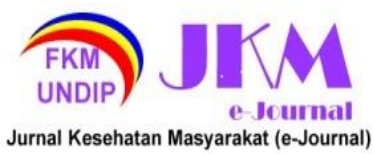

pemberian makanan yang diberikan tetapi dapat disebabkan karena kurangnya pengetahuan orang tua terutama ibu tentang gizi yang berkaitan dengan kandungan makanan cara pengolahan makanan, kebersihan makanan dan lain-lain, selain pengetahuan ibu, keadaan ekonomi yang rendah juga mempengaruhi pola konsumsi makanan keluarga. ${ }^{8}$

Penelitian yang dilaksanakan di Kabupaten Banyumas Tahun 2010 mennjukkan bahwa pemberian MPASI ditujukan untuk menambah zat-zat gizi yang diperlukan bayi karena ASI sudah tidak dapat memenuhi kebutuhan bayi untuk menjamin tumbuh kembang balita. ${ }^{8}$ Sesuai juga dengan penelitian yang dilakukan pada baduta usia 624 bulan sebanyak 60 orang di desa Pannampu kecamatan Tallo, Makassar. ${ }^{6}$

Hasil uji Chi Square menunjukkan bahwa kesesuaian tekstur MPASI berhubungan dengan tingkat kecukupan energi baduta $(p=0,019)$ tetapi tidak berhubungan dengan tingkat kecukupan protein baduta $(p=0,462)$.

Sesuai dengan pernyataan $\mathrm{WHO}$, tekstur MPASI yang diberikan harus didasarkan dengan tingkatan usia baduta dan diberikan secara bertahap sehingga pertumbuhan baduta menjadi optimal. ${ }^{9}$ Tekstur yang tidak sesuai berpengaruh terhadap proses pengunyahan makanan yang berpengaruh terhadap energi yang dikeluarkan oleh baduta. Tidak adanya hubungan antara kesesuaian tekstur MPASI dengan tingkat kecukupan protein berkaitan dengan lauk pauk yang dikonsumsi baduta mengandung protein tinggi sehingga mencukupi kebutuhan protein baduta.

Jenis MPASI yang diberikan dihubungkan dengan tingkat kecukupan energi dan protein baduta dengan menggunakan uji Chi Square. Hasil uji statistik menunjukkan tidak ada hubungan antara jenis MPASI yang diberikan dengan tingkat kecukupan energi $(p=0,067)$ tetapi berhubungan dengan tingkat kecukupan protein $(p=0,043)$.

$\mathrm{Hal}$ ini sesuai dengan penelitian sebelumnya pada 15 bayi usia $6-12$ bulan yang diberi MPASI pabrikan dan 15 lainya diberi MPASI lokal, yang menunjukkan bahwa pemberian MPASI lokal dan instan akan menghasilkan tingkat kecukupan energi yang cukup selama diberikan dalam porsi yang cukup. ${ }^{10}$

Hasil tabel Crosstab baduta dengan pemberian MPASI instant sebagian besar memiliki tingkat kecukupan protein cukup $(66,7 \%)$. Baduta yang diberi MPASI lokal sebagian besar memiliki tingkat kecukupan protein lebih $(75 \%)$ dan baduta yang diberi MPASI instan dan lokal, sebagian besar memiliki tingkat kecukupan protein yang lebih $(83,3 \%)$. Baduta dengan pemberian MPASI lokal sebagian besar memiliki tingkat kecukupan protein lebih sebab sumber MPASI lokal yang diberikan merupakan hasil tangkapan laut yang berupa ikan dan hasil laut lainnya. Penelitian sebelumnya terkait perbandingan antara MPASI lokal dan MPASI pabrikan (instan) menyatakan bahwa MPASI lokal $(64,45 \%)$ lebih banyak dikonsumsi dibanding dengan MPASI instan (35,6\%). Pemberian MPASI yang cukup dan sesuai dengan anjuran yang diberikan akan memberikan kecukupan gizi anak. ${ }^{11}$

\section{KESIMPULAN}

Frekuensi dan durasi pemberian ASI berhubungan dengan TKE, tetapi tidak berhubungan dengan TKP. Pemberian MPASI tidak berhubungan dengan TKE baduta. Frekuensi dan jenis MPASI berhubungan dengan TKP baduta, tetapi kesesuaian tekstur MPASI tidak berhubungan.

\section{SARAN}

Frekuensi dan durasi pemberian ASI perlu akan berkurang seiring bertambahnya usia. Pemenuhan MPASI baduta desa Betahwalang perlu memeperhatikan pemenuhan kebutuhan energinya. Penambahan porsi nasi dapat menambah kebutuhan energinya.

\section{DAFTAR PUSTAKA}

1. Soetjiningsih. ASI Petunjuk untuk Tenaga Kesehatan. Jakarta: EGC; 1997.

2. World Health Organization, Unicef. Global strategy for infant and young child feeding. Geneva, Swiss: World Health Organization; 2003.

3. Ministry of Health Indonesia. Data dan informasi profil kesehatan Indonesia 2018 [Indonesia Health Profile 2018]. 2019;207.

4. Kementerian Kesehatan, RI. 2014. Pedoman gizi seimbang, Jakarta.

5. Hariani RE, Amareta DI, Arinda D, Suryana L, Kesehatan J, Jember PN. Pola pemberian asi dan makanan pendamping asi terhadap grafik pertumbuhan pada kartu menuju sehat (kms). J IIm Inov. 2016;1(1):41-6.

6. Susanty, M., Kartika M., Veni., H., dan Alharini, S. Hubungan Pola Pemberian Asi dan $\mathrm{Mp}$ Asi dengan gizi buruk pada anak 6-24 bulan di Kelurahan Pannampu 
Makassar. Jurnal Media Gizi Masyarakat Indonesia 2012; 2(1): 97-103.

7. Soetjiningsih. ASI Petunjuk untuk Tenaga Kesehatan. Jakarta: EGC; 1997.

8. Fatimah, S., Ikeu N., dan Windy R. Faktorfaktor yang berkontribusi terhadap status gizi pada balita Di Kecamatan Ciawi Kabupaten Tasikmalaya. 2008; 10(18); 37.

9. WHO. Infant and young child feeding counseling : An Integrated Course;2006

10. Triana, A, Liva Maita. Pengaruh pemberian MPASI pabrikan dan MPASI lokal terhadap status gizi bayi. Jurnal Media Kesehatan 2019; 12(1):040-044

11. Olivia, M., Mayulu, N., Kawengian, S. Gambaran pemberian makanan pendamping ASI anak usia 6-24 bulan di Desa Mopusi Kecamatan Lolayan Kabupaten Bolaang Mongondow Induk. Jurnal e-Biomedik (eBm). Juli-Desember 2016;4(2) Manado.

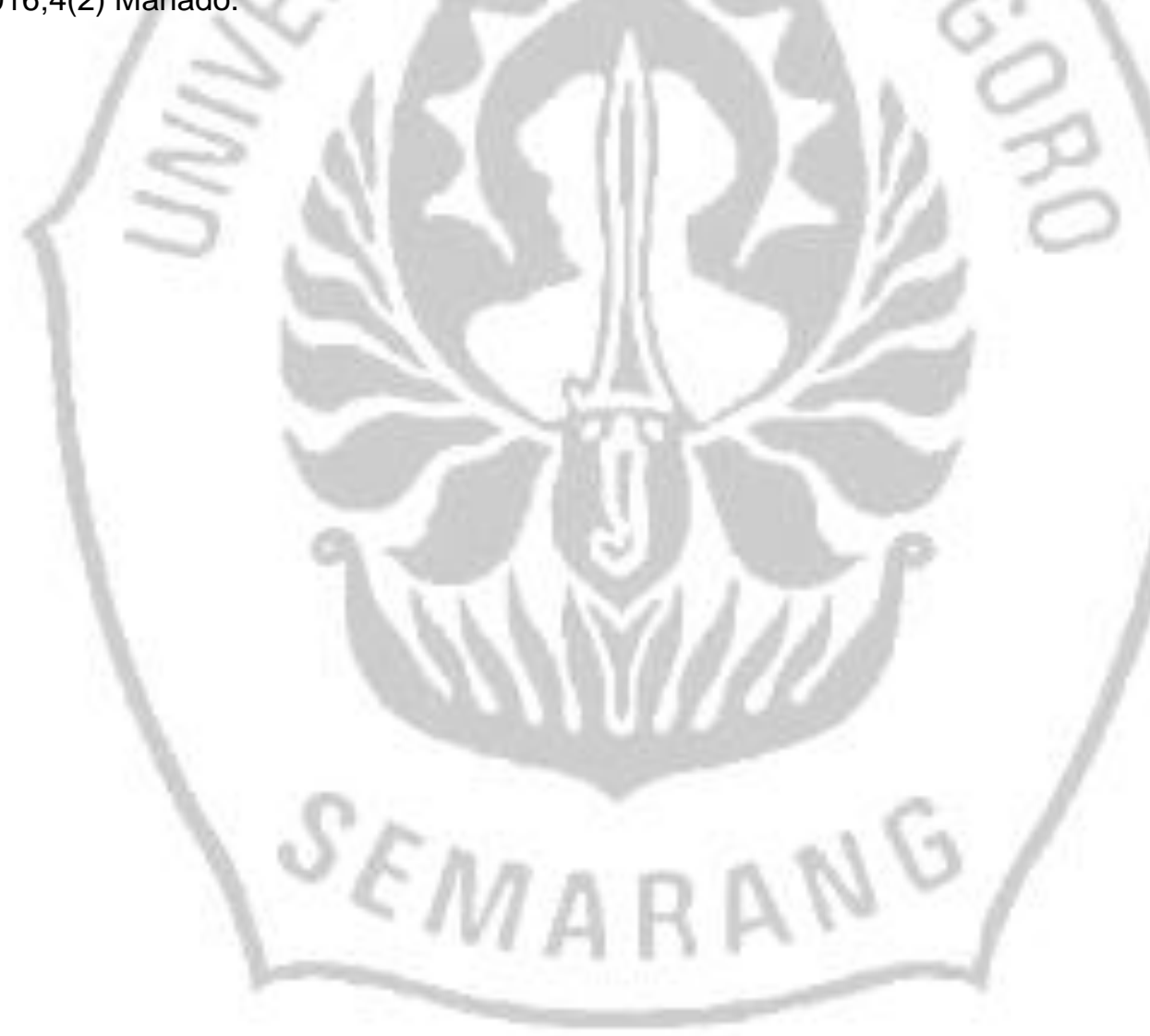

